\title{
TLX1 Gene
}

National Cancer Institute

\section{Source}

National Cancer Institute. TLX1 Gene. NCI Thesaurus. Code C18608.

This gene plays a role in transcriptional regulation and organogenesis. Translocations in the gene are associated with acute T-cell leukemia. 